\title{
Assessment of the anti-virulence potential of extracts from four plants used in traditional Chinese medicine against multidrug-resistant pathogens
}

Zhonghui Pu ${ }^{1,2+}$, Huaqiao Tang ${ }^{1,2+}$, Nana Long ${ }^{1,2}$, Min Qiu', Mingxiang Gao ${ }^{3}$, Fenghui Sun ${ }^{1,2^{*}}$ and Min Dai ${ }^{1,2^{*}}$

\begin{abstract}
Background: Multidrug-resistant pathogens are resistant to many antibiotics and associated with serious infections. Amomum tsaoko Crevost et Lemaire, Sanguisorba officinalis, Terminalia chebula Retz and Salvia miltiorrhiza Bge, are all used in Traditional Chinese Medicine (TCM) against multidrug-resistant pathogens, and the purpose of this study was to evaluate the antibacterial and anti-virulence activity of extracts derived from them.

Methods: The antibacterial activity of ethanol and aqueous extracts from these four plants was examined against several multi-drug resistant bacterial strains, and their anti-virulence potential (including quorum quenching activity, biofilm inhibition, and blocking production of virulence factor $\delta$-toxin) was assessed against different $S$. aureus strains. The chemical composition of the most effective extract was determined by LC-FTMS.

Results: Only extracts from S. officinalis and A. tsaoko were shown to exhibit limited growth inhibition activity at a dose of $256 \mu \mathrm{g} \cdot \mathrm{mL}-1$. The S. officinalis ethanol extract, the ethanol and aqueous extract of A. tsaoko, and the aqueous extract of S. miltiorrhiza all demonstrated quorum quenching activity, but didn't significantly inhibit bacterial growth. The ethanol extract of S. officinalis inhibited bacterial toxin production and biofilm formation at low concentrations. Chemical composition analysis of the most effective extract of $\mathrm{S}$. officinalis showed that it mainly contained saponins.
\end{abstract}

Conclusions: The most active extract tested in this study was the ethanol root extract of S. officinalis. It inhibited $\delta$ toxin production and biofilm formation at low concentrations and saponins may be its key active components. While the four plants showed no direct antibacterial effects, their anti-virulence properties may be key to fighting bacterial infections.

Keywords: TCM plants, Quorum sensing inhibition, Virulence, Biofilm

\footnotetext{
*Correspondence: sunfenghui@cmc.edu.cn; daimin1019@163.com

${ }^{\dagger}$ Zhonghui Pu and Huaqiao Tang contributed equally to this work.

${ }^{1}$ School of Laboratory Medicine, Chengdu Medical College, Chengdu, Sichuan, People's Republic of China

Full list of author information is available at the end of the article
}

C C The Author(s). 2020 Open Access This article is licensed under a Creative Commons Attribution 4.0 International License, which permits use, sharing, adaptation, distribution and reproduction in any medium or format, as long as you give appropriate credit to the original author(s) and the source, provide a link to the Creative Commons licence, and indicate if changes were made. The images or other third party material in this article are included in the article's Creative Commons licence, unless indicated otherwise in a credit line to the material. If material is not included in the article's Creative Commons licence and your intended use is not permitted by statutory regulation or exceeds the permitted use, you will need to obtain permission directly from the copyright holder. To view a copy of this licence, visit http://creativecommons.org/licenses/by/4.0/ The Creative Commons Public Domain Dedication waiver (http://creativecommons.org/publicdomain/zero/1.0/) applies to the data made available in this article, unless otherwise stated in a credit line to the data. 


\section{Background}

The advent of antibiotics in the early twentieth century greatly reduced the mortality associated with infection. However, overuse or abuse of antibiotics has led to bacterial resistance becoming a serious global public health problem [1]. Drug-resistant bacterial infections have a huge burden on health care systems, veterinary practices, and society in general, and have an impact on a wide range of sectors, from farms to public health [2]. The antibiotic resistance levels of a large number of drugresistant pathogens, including Enterobacteriaceae, Campylobacter, and Candida, are increasing [3]. Some bacteria are, or are about to be become, resistant to almost all antibiotics, such as the Carbapenem-resistant Enterobacteriaceae and the multi-drug resistant Acinetobacter [4]. The consequences of drug-resistant bacteria infections are serious and can include an extended duration of illness, longer hospital stays, higher mortality rates, and increased hospitalization costs [5]. Bacterial resistance to antibiotics not only threatens health, but also brings economic losses.

Antibiotic abuse, including incorrect usage, inaccurate dosages, frequency of use, and improper treatment, will lead to bacterial resistance and eventually promote the emergence of super bacteria [6]. Fluoroquinolones are used in large quantities in China, and resistance to these antibiotics has reached $60 \%$ [7]. In the past, skin and visceral infections caused by S.aureus were effectively treated with penicillin, but methicillin-resistant Staphylococcus aureus has now become the dangerous pathogens in nosocomial infections [8]. After carbapenem was introduced to China it became one of the main antibacterial drugs used to treat severe bacterial infections, but recently, there is an increasing in the number of carbapenem-resistant bacteria, with the most common being Escherichia coli, Staphylococcus aureus, Klebsiella pneumoniae and Streptococcus pneumoniae, followed by Salmonella [9]. A combination of the decline in the antibacterial efficacy of antibiotics and a lack of research on new antibiotics, means that a new antiinfection strategy should be established, and the antivirulence method is thought to be a potentially effective way [10].

Traditional Chinese medicine (TCM) is a unique natural resource in China, with a long history in preventing and treating infectious diseases $[11,12]$. The biggest feature and advantage of its anti-infection medicine is that it exerts anti-infective effects at an overall level. While TCMs have anti-infective properties, many also have antipyretic and anti-inflammatory effects [13]. TCMs anti-infective properties are strengthened by their functional enhancement of the body's immune system [14]. Studies have shown that the bacteriostatic effect of TCM is related to the molecular structure of its active ingredients [15]. However, there have been minimal studies on the use of TCM to combat infection through anti-virulence mechanisms [16].

In this study, we selected four plants commonly used in TCM; Amomum tsaoko Crevost et Lemaire, Sanguisorba officinalis, Terminalia chebula Retz, and Salvia miltiorrhiza Bge. We examined the antibacterial activity of ethanol and aqueous extracts from these plants against the following multi-drug resistant bacterial strains, A. baumannii, E. aerogenes, E. cloacae, E. faecium, K. pneumoniae, P. aeruginosa, and S. aureus, and tested their anti-virulence potential against various $S$. aureus strains. We used $S$. aureus biosensor strains to assess the quorum sensing inhibition potential of the extracts, and to evaluate the $\delta$-toxin synthesisas and biofilm formation inhibition effects of the most active extracts.

\section{Methods}

\section{Preparation of the different extracts}

Four plants commonly used in TCM (fruits of Amomum tsaoko Crevost et (\#:20180705), root of Sanguisorba officinalis (\#:1811096), fruits of Terminalia chebula (\#:1811035) and root of Salvia miltiorrhiza (\#:1811035) were purchased from Sichuan Neo-Green Pharmaceutical Technology Development Co., Ltd. (Pengzhou, China), in September 2018 and identified by Prof. Min Li.

Material from A.tsaoko, S. officinalis, T. chebula, and S. miltiorrhiza were air-dried and ground into a powder. To prepare the ethanol raw extracts, the powder was macerated at a ratio of 1:10 (w / v) in $1 \mathrm{~L}$ flasks for $72 \mathrm{~h}$ in $70 \%$ ethanol with regular agitation. The macerate was filtered and stored, and the residual plant material was reprocessed in $70 \%$ ethanol. The two macerates were combined and evaporated under reduced pressure using a rotary evaporator at $\leq 40{ }^{\circ} \mathrm{C}$ to obtain a dark brown residue, which were dissolved in $\mathrm{dH}_{2} \mathrm{O}$ and shell frozen in a dry ice-acetone bath before being lyophilized. Dried extracts were stored in scintillation vials at $-20^{\circ} \mathrm{C}$. Each plant sample $(30 \mathrm{~g})$ was subjected to distilled water (1:10 ratio $\mathrm{w} / \mathrm{v}$ ) for $20 \mathrm{~min}$ on a hot plate, followed by centrifugation and vacuum filtration to obtain aqueous extracts. The all extracts were dissolved to $10 \mathrm{mg} \mathrm{mL}^{-1}$ in DMSO for biological assays.

\section{Bacterial strains and culture conditions}

The multi-drug resistant bacteria used in this study (Table 2 and Table S1); Acinetobacter baumannii (EU24, CDC-33), Enterobacter aerogenes (CDC-7) and Enterobacter cloacae (CDC-32); Enterococcus faecium (EU49, EU-44), Klebsiella pneumoniae (EU-32, CDC-76), Pseudomonas aeruginosa (PAO1, CDC-54), and Staphylococcus aureus (AH845, NRS249, NRS232, 
NRS252), which were stored in Quave's Lab (Emory University, Full details in Supplementary Table S1). All strains were grown on trypticase soy agar (TSA) plates and incubated at $37^{\circ} \mathrm{C}$ for $12 \mathrm{~h}$, then single colonies were picked and cultured in either Cation-adjusted Mueller Hinton II broth (CAMHB) or tryptic soy broth (TSB). All antibacterial tests were repeated three times and multiple independent experiments performed.

\section{Growth inhibition analyze}

Extracts were screened for growth inhibition activity as previously reported [17]. Overnight liquid cultures grown in CAMHB were diluted to a confluence of $5 \times$ $10^{5} \mathrm{CFU} \mathrm{mL} \mathrm{m}^{-1}$ as determined by on their optical density $\left(\mathrm{OD}_{600}\right)$. Assays were conducted in 96-well plates (CELL STAR 655-185). Plates were incubated for $24 \mathrm{~h}$ and the $\mathrm{OD}_{600}$ were read by a Cytation-3 multimode plate reader (Biotek), after which, the percentage of growth inhibition was calculated. The OD was also used to calculate the $\mathrm{IC}_{50}$, and where the $\mathrm{IC}_{50} \leq 256 \mu \mathrm{g} \cdot \mathrm{mL}^{-1}$, the dosedependent anti-bacterial activity of the extract was tested.

\section{Agr reporters were used for quorum sensing assay}

The quorum sensing inhibition activity of the extracts were evaluated by using the accessory gene regulator (agr) reporters of S. aureus, including AH1672, AH430, AH1747, and AH1872, according to previously described [10]. Quorum sensing inhibition activity of the extracts was equal to the reporter strains fluorescent protein (YFP) signal. The agr reporter strains were grown in TSA and maintained TSB, supplemented with chloramphenicol $\left(10 \mu \mathrm{g} \cdot \mathrm{mL}^{-1}\right)$. All anti-quorum sensing assays were conducted in black 96-well microtiter plates (Costar 3603, final well volume: $200 \mu \mathrm{L}$ ). Plates were incubated in a humidified shaker at $37^{\circ} \mathrm{C}$ at $1200 \mathrm{rpm}$ (Stuart SI505). The $\mathrm{OD}_{600}$ and fluorescence (493 nm excitation, $535 \mathrm{~nm}$ emission) were measured by a plate reader at $0 \mathrm{~h}$ and $22 \mathrm{~h}$ incubation (BioTek Cytation3). The initial concentration of $256 \mu \mathrm{g} \mathrm{mL}^{-1}$ were selected to against agr 1-4 reporter strains. Dose response curves were tested by 2 -fold serial dilutions method for a final concentration range from 2 to $256 \mu \mathrm{gL}^{-1}$.

\section{Quantification of $\delta$-toxin production}

The most active extracts determined by the agr reporter assay were selected to against the $\delta$-toxin production of S. aureus strains (AH1262 and NRS249) as previously described [18]. The sub-inhibitory concentrations of the extracts with a final volume of $1.5 \mathrm{~mL}$ were used in the assay. The tubes were incubated at $37^{\circ} \mathrm{C} / 275 \mathrm{rpm}$ for 15 $\mathrm{h}$, then samples were collected after the $\mathrm{OD}_{600}$ determined. All the samples were centrifuged at 13,000 $\mathrm{g}$ for $5 \mathrm{~min}$ at $4{ }^{\circ} \mathrm{C}$ and supernatants were moved to a vial for $\delta$-toxin quantification by HPLC. Formylated and deformylated $\delta$-toxin were normalized for growth $\left(\mathrm{OD}_{600}\right)$ during supernatant harvest [19].

\section{Biofilm inhibition assay}

The anti-virulence potential of the most active extracts determined by the agr reporter assay were determined by their biofilm inhibiting activity, assessed using a crystal violet assay, as previously described [20]. Briefly, after culturing the bacterial biofilm in a microplate, the culture solution was removed, the plate washed with PBS and dried, and the $1 \%$ crystal violet solution was added. After incubating for $30 \mathrm{~min}$, the excess dye was washed off with water, and the dye attached to the biofilm is dissolved with ethanol or acetic acid. The OD was measured at $590 \mathrm{~nm}$ with a microplate reader. S. aureus strains UAMS-1 and UAMS-929 (isogenic biofilm deficient mutant of UAMS-1) were used in the assay [21].

\section{Chemical characterization of extracts}

Officinalis EtOH extracts, which was determined to be the most effective extract in terms of antibacterial, antivirulence, and anti-biofilm activities, was characterized by LC-FTMS using a Thermo Scientific LTQ-FT Ultra mass spectrometer equipped with a Shimadzu SILACHT auto sampler and Dionex 3600SD HPLC pump. An Agilent Eclipse XDB column $(250 \times 4.6 \mathrm{~mm})$ packed with $\mathrm{C} 18(5 \mu \mathrm{m})$ was used for analysis. Extracts were dissolved to10 $\mathrm{mg} \mathrm{mL}^{-1}$ in $\mathrm{MeOH}$ and passed through $0.45 \mu \mathrm{m}$ filters and then $20 \mu \mathrm{L}$ sample was injected by autosampler. Gradient elution was carried out with the solvent system A ( $0.1 \%$ formic acid) and system B $(0.1 \%$ formic acid in $\mathrm{ACN}$ ) at a flow rate of $1 \mathrm{~mL} \mathrm{~min}^{-1}$, and the gradient steps were set from $98 \%$ A to $90 \%$ A in 19 $\mathrm{min}$, to $85 \% \mathrm{~A}$ in $40 \mathrm{~min}$, to $100 \% \mathrm{~A}$ in $66 \mathrm{~min}$, before returning the column to initial conditions $98 \% \mathrm{~A}$ in 9 min. For all samples, data was collected from 190 to 600 $\mathrm{nm}$ using a diode array detector. MS data were acquired in MS1 mode in negative ESI (electrospray ionization) and positive ESI (electrospray ionization) mode at 150$1500 \mathrm{~m} / \mathrm{z}$ and processed using Thermo Scientific Xcalibur 2.2 SP1.48 (San Jose, California). The capillary temperature of the negative and positive modes was $275.0^{\circ} \mathrm{C}, 60$ sheath gas, source voltage of $5.00 \mathrm{kV}$, source current of $100.0 \mu \mathrm{A}$, and capillary voltage of -19.0 or + $32.0 \mathrm{~V}$. The presumed formula of extract components was determined using $\mathrm{X}$-caliber software to perform isotope abundance analysis of the high-resolution mass spectrometry data and report the best matching empirical formula. Database searches were performed using Scifinder (American Chemical Society) and Natural Product Dictionary (Taylor \& Francis Group) and compounds with molecular masses corresponding to the 
above LC-FTMS data which had been previously identified from the same plant species were reviewed.

\section{Statistical analysis}

All of the data were analyzed with a two-tailed Student's t-test by GraphPad Prism 8.0 (GraphPad Software, La Jolla, CA). Cultures treated with DMSO or dH2O were used as vehicle controls, which were compared to extracts treated samples for all statistical analyses. ${ }^{*} p<0.05$ or ** $p<0.01$ was considered to be statistically significant.

\section{Results}

\section{Limited growth inhibitory activity was confirmed in}

\section{ESKAPE pathogens}

To determine their growth inhibition activity, crude extracts (Table 1) were screened against each ESKAPE pathogen at $256 \mu \mathrm{g} \cdot \mathrm{mL}^{-1}$. Dose-response experiments were performed for extracts when the inhibition percentage above 40 for any individual strain. After the initial library screen, the EtOH and aqueous S. officinalis extracts and the EtOH $A$. tsaoko extracts showed significant activity and were therefore evaluated from further assay. The inhibitory activity of the $\mathrm{EtOH}$ and aqueous extracts is shown in Table 2.

\section{Active extracts exhibited dose related antibacterial activity}

As shown in Fig. 1, the S. officinalis ethanol extract inhibited Acinetobacter baumannii strain (CDC-33) and $S$. aureus (AH845) growth with an $\mathrm{IC}_{50}$ of $256 \mu \mathrm{g} \cdot \mathrm{mL}^{-1}$. The $S$. officinalis aqueous extract inhibited $A$. baumannii strain (CDC-33) with an $\mathrm{IC}_{50}$ of $256 \mu \mathrm{g} \cdot \mathrm{mL}^{-1}$ and the ethanol extract inhibited $A$. baumannii strain (EU-24) and $P$. aeruginosa strain (CDC-54), with an $\mathrm{IC}_{50}$ of 128 and $256 \mu \mathrm{g} \cdot \mathrm{mL}^{-1}$ respectively.
Table 1 The parts used, extract ID, extraction solvent and yields of the plant species

\begin{tabular}{lllll}
\hline Plant species & Part used & Extract ID & Extract solvent & Yield (\%) \\
\hline T. chebula & & & & \\
& Fruits & CDY 1 & $\mathrm{EtOH}$ & 7.64 \\
& Fruits & $\mathrm{CDY} 2$ & $\mathrm{dH}_{2} \mathrm{O}$ & 9.35 \\
S. officinalis & & & & \\
& Root & $\mathrm{CDY} 3$ & $\mathrm{EtOH}$ & 10.46 \\
& Root & $\mathrm{CDY} 4$ & $\mathrm{dH}_{2} \mathrm{O}$ & 7.82 \\
A. tsaoko & & & & \\
& Fruits & $\mathrm{CDY} 5$ & $\mathrm{dH}_{2} \mathrm{O}$ & 7.56 \\
& Fruits & $\mathrm{CDY} 6$ & $\mathrm{EtOH}^{2}$ & 9.38 \\
& Fruits peel & $\mathrm{CDY} 7$ & $\mathrm{dH}_{2} \mathrm{O}$ & 8.93 \\
S. miltiorrhiza & & & & 8.25 \\
& Root & $\mathrm{CDY} 8$ & $\mathrm{dH}_{2} \mathrm{O}$ & 7.84 \\
\hline
\end{tabular}

Extracts exhibited quorum quenching activity in S. aureus In $S$. aureus, the accessory gene regulator (agr) system plays an important role in the production of virulence factors by quorum-sensing component pathways [22]. The four allelic groups on the agr gene locus, agr I-IV [23], have been confirmed by genetic and agr-inhibiting methods [24]. We screened the quorum quenching activity of these extracts against $S$. aureus and the results are shown in Fig. 2. The S. officinalis EtOH extract exhibited dose dependent quorum quenching activity against Agr 1-4, but showed no anti-bacterial activity against Agr 2-4. The organic and aqueous extracts of $A$. tsaoko showed no anti-bacterial activity against the Agr strains, but significantly inhibited the quorum sensing of Agr 1-3. All other extracts, except for the S. miltiorrhi aqueous extract, showed quorum quenching activity against Agr 1.

Table 2 The growth inhibition results of selected ESKAPE pathogens by four medicinal plant samples

\begin{tabular}{|c|c|c|c|c|c|c|c|c|c|c|c|c|c|c|c|}
\hline \multirow[t]{2}{*}{$\begin{array}{l}\text { Plant } \\
\text { Species }\end{array}$} & \multirow[t]{2}{*}{$\begin{array}{l}\text { Extract } \\
\text { ID }\end{array}$} & \multicolumn{2}{|c|}{ A. baumannii } & \multirow{2}{*}{$\begin{array}{l}\text { E. } \\
\text { aerogenes } \\
\text { CDC-7 }\end{array}$} & \multirow{2}{*}{$\begin{array}{l}E . \\
\text { cloacae } \\
\text { CDC-32 }\end{array}$} & \multicolumn{2}{|c|}{ E. faecium } & \multicolumn{2}{|c|}{$\begin{array}{l}\text { K. } \\
\text { pneumoniae }\end{array}$} & \multicolumn{2}{|c|}{ P. aeruginosa } & \multicolumn{4}{|c|}{ S. aureus } \\
\hline & & $\begin{array}{l}\mathrm{CDC}- \\
33\end{array}$ & $\begin{array}{l}\text { EU- } \\
24\end{array}$ & & & $\begin{array}{l}\text { EU- } \\
44\end{array}$ & $\begin{array}{l}\text { EU- } \\
49\end{array}$ & $\begin{array}{l}\text { EU- } \\
32\end{array}$ & $\begin{array}{l}\text { CDC- } \\
76\end{array}$ & $\begin{array}{l}\text { CDC- } \\
54\end{array}$ & PAO1 & $\mathrm{AH} 845$ & NRS249 & NRS232 & NRS252 \\
\hline \multirow[t]{2}{*}{ T. chebula } & CDY 1 & - & - & - & - & - & - & - & - & - & - & - & - & - & - \\
\hline & CDY 2 & - & - & - & - & - & - & - & - & - & - & - & - & - & - \\
\hline \multirow[t]{2}{*}{ S. officinalis } & CDY 3 & + & - & - & - & - & - & - & - & - & - & + & - & - & - \\
\hline & CDY 4 & + & - & - & - & - & - & - & - & - & - & - & - & - & - \\
\hline \multirow[t]{3}{*}{ A. tsaoko } & CDY 5 & - & - & - & - & - & - & - & - & - & - & - & - & - & - \\
\hline & CDY 6 & - & + & - & - & - & - & - & - & + & - & - & - & - & - \\
\hline & CDY 7 & - & - & - & - & - & - & - & - & - & - & - & - & - & - \\
\hline \multirow{2}{*}{$\begin{array}{l}\text { S. } \\
\text { miltiorrhiza }\end{array}$} & CDY 8 & - & - & - & - & - & - & - & - & - & - & - & - & - & - \\
\hline & CDY 9 & - & - & - & - & - & - & - & - & - & - & - & - & - & - \\
\hline
\end{tabular}



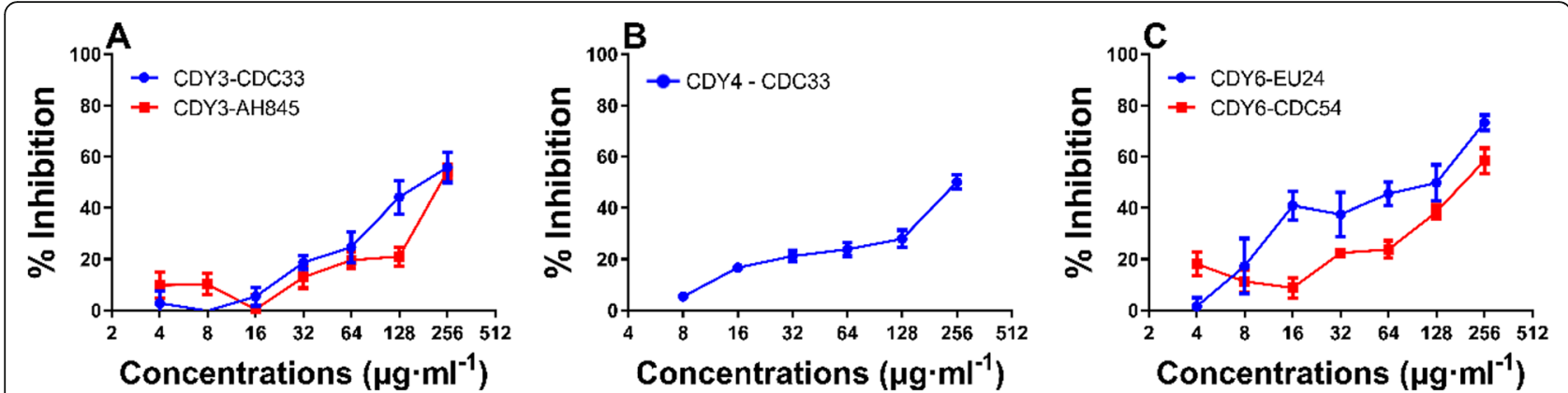

Fig. 1 Extract mediated growth inhibition of selected ESKAPE pathogens. a Inhibition of CDC33 and AH845 by CDY3, b Inhibition of CDC33 by CDY4, c Inhibition of EU24 and CDC54 by CDY6

Extracts block production of virulence factor $\delta$-toxin in $S$. aureus

The strains AH 1263 and NRS 249 produce high levels of $\delta$-toxin. Toxin levels were measured after strains were treated with CDY 3, 5, 6, and 9 (extracts which exhibited quorum quenching activity). CDY3, 6 and 9 significantly inhibited $\delta$-toxin production in $S$. aureus (NRS 249) and CDY 3, 5, 6, and 9 showed dose dependent inhibition of $\delta$-toxin produced by $S$. aureus. All inhibitory effects were produced without inhibiting bacterial growth (Fig. 3). CDY 3 exhibited the most effective anti- $\delta$-toxin activity at a concentration of $128 \mu \mathrm{g} \cdot \mathrm{mL}^{-1}$.

Extracts exhibit inhibition of $S$. aureus biofilm

The inhibition activity of the extracts against biofilm formation was tested with $S$. aureus strains UAMS-929 and UAMS-1. Sar is a winged helix transcription factor that can regulate biofilm formation. UAMS-929 has the sar

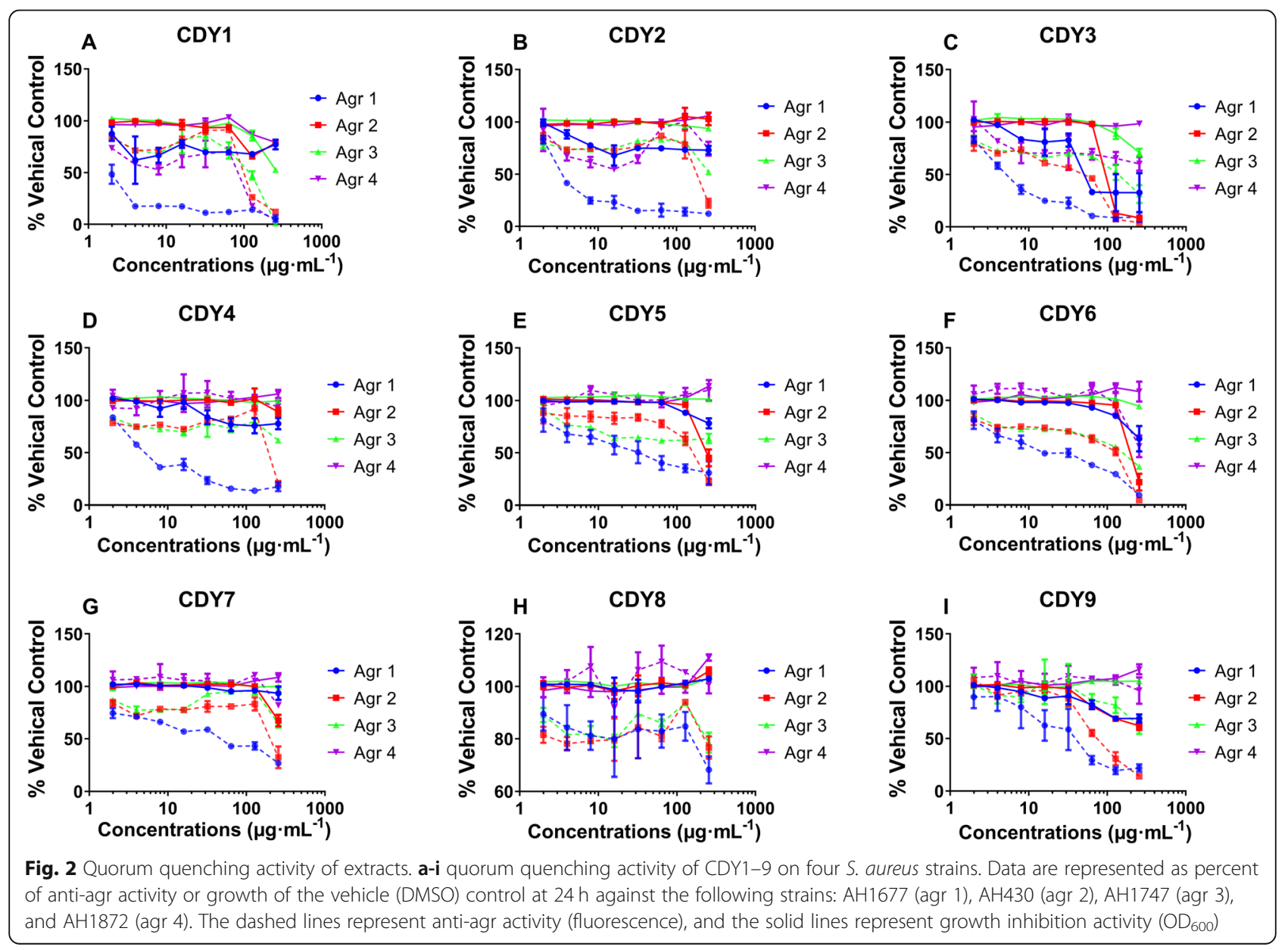



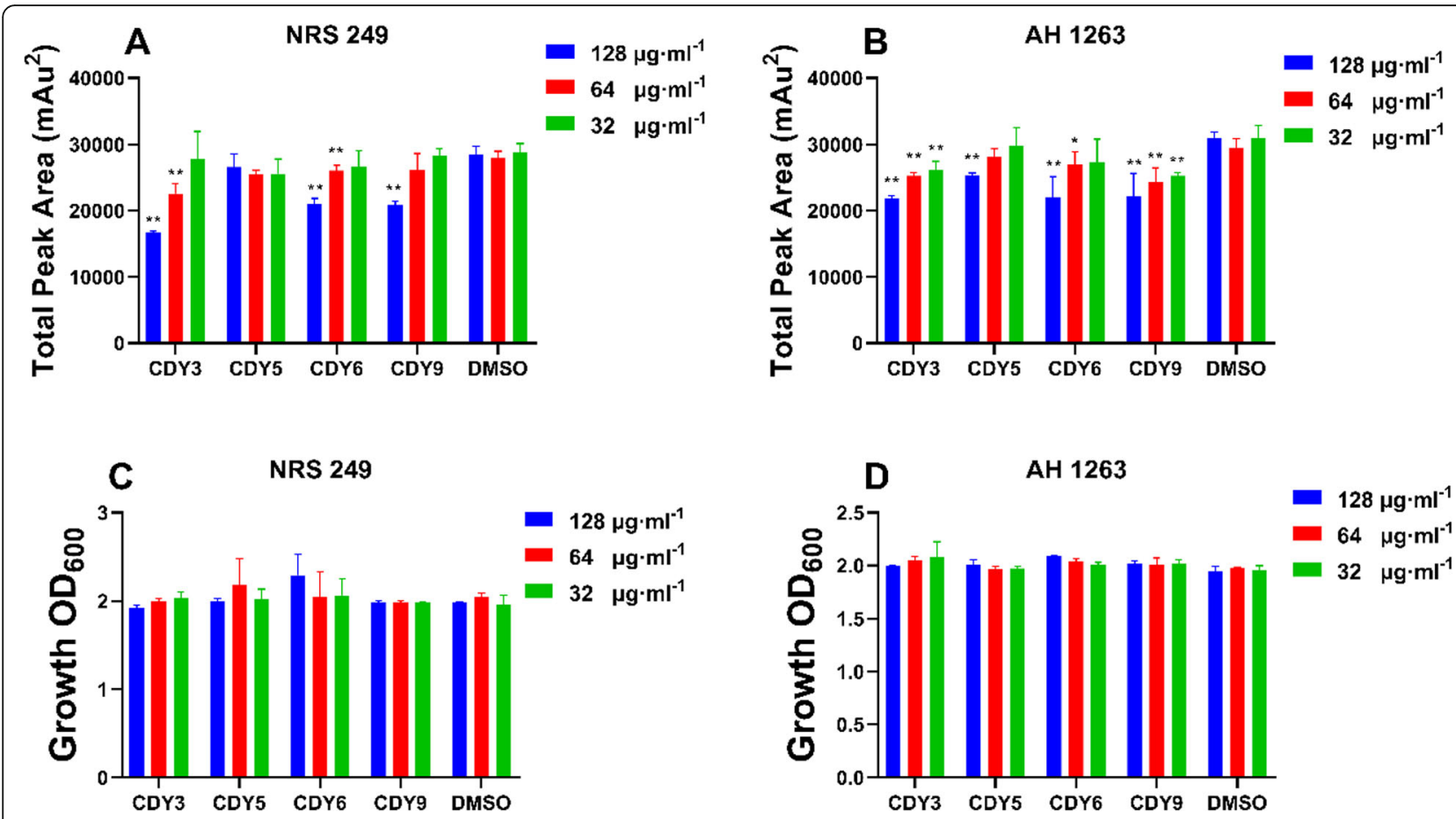

Fig. 3 Extracts block $\delta$-toxin production without exhibiting antibacterial activity. a, b CDY3, 5, 6 and 9 inhibition of $\delta$-toxin production in NRS249 and AH1263, c, d CDY3, 5, 6 and 9 inhibition of NRS249 and AH1263 growth. ${ }^{*} p<0.05$ or ${ }^{* *} p<0.01$ vs. DMSO

gene knocked out and cannot produce biofilms and thus is used as a control. CDY3 showed the best biofilm inhibition activity in a dose related manner, CDY6 and CDY9 also inhibited biofilm formation, but only at higher doses, and CDY5 exhibited limited biofilm inhibition. The results are shown in Fig. 4.

\section{Chemical characterization of active extracts}

Characterization of the major constituents of the ethanol extract of S. officinalis. All peaks correspond to the data presented in Supplementary materials. Table S2 and S3, and putative structural matches are listed by peak number (Fig. 5). Peak 1 was determined to be $\mathrm{C}_{36} \mathrm{H}_{58} \mathrm{O}_{9}$ and putative structural matches include; Olean-12-en-28-oic acid, 3,19-dihydroxy-, $\beta$-D-glucopyranosyl ester, (3ß, $19 \alpha)$. Peak 2 was determined to be $\mathrm{C}_{41} \mathrm{H}_{64} \mathrm{O}_{13}$ and putative structural matches include; $\beta$-D-Glucopyranose, 1 $[(2 \mathrm{~S}, 4 \mathrm{aS}, 4 \mathrm{bR}, 6 \mathrm{aR}, 8 \mathrm{~S}, 10 \mathrm{aS}, 10 \mathrm{bR})-8$ - ( $\alpha$-L-arabinopyranosyloxy) - 2,3,4,4a,4b,5,6,6a,7,8,9,10,10a,10b-tetradecahydro-4a,4b,7,7,10a-pentamethyl-2-[(3R)-3-methyl-4-

oxopentyl]-2-chrysenecarboxylate]. Peak 5 was assayed to be $\mathrm{C}_{36} \mathrm{H}_{56} \mathrm{O}_{12}$ and putative structural matches include; Urs-12-ene-23,28-dioic acid, 2,3,19-trihydroxy-, $28-\beta$-D-glucopyranosyl ester, $(2 \alpha, 3 \beta, 4 \alpha)$-. Peak 6 was determined to be $\mathrm{C}_{30} \mathrm{H}_{27} \mathrm{O}_{12}$ and putative structural matches include; D-Ribofuranoside, methyl 3-O-methyl2-C-[[(3,4,5-trimethoxybenzoyl) oxy] methyl]-, 5-(3,4,5trimethoxybenzoate). Peak 9 was determined to be
$\mathrm{C}_{35} \mathrm{H}_{57} \mathrm{O}_{8}$ and putative structural matches include; Olean-12-en-28-oic acid, 3-( $\alpha$-L-arabinopyranosyloxy)19-hydroxy-, $(3 \beta, 19 \alpha)$-. Peak 10 was determined to be $\mathrm{C}_{30} \mathrm{H}_{62} \mathrm{O}$ and putative structural matches include; 1Triacontanol. Peak 11 was determined to be $\mathrm{C}_{36} \mathrm{H}_{58} \mathrm{O}_{10}$ and putative structural matches include; Urs-12-en-28oic acid, 2,3,19-trihydroxy-, $\beta$-D-glucopyranosyl ester, $(2 \alpha, 3 \alpha)$-. Peak 12 was determined to be $\mathrm{C}_{30} \mathrm{H}_{45} \mathrm{O}_{5}$ and putative structural matches include; Urs-12-en-28-oic acid, 19-hydroxy-3,11-dioxo-. This shows that the active ingredients of the EtOH extract mainly include saponins, flavonoids, phenolic glycosides, and lignins.

\section{Discussion}

Traditional Chinese Medicine and its compounds have comprehensive therapeutic effects including inhibiting virus replication, preventing virus-induced cytopathy, and regulating immune function, as well as analgesic and anti-inflammatory properties. It therefore has unique advantages and broad development prospects for the prevention and treatment of infectious diseases [25]. However, many studies have shown that the antiinfective effect of Chinese medicine may not depend on its anti-bacterial properties, and some traditional medicines used to treat infections do not exhibit any antibacterial effects. In this study, only the organic and aqueous extracts of $S$. officinalis and the ethanol extract of $A$. tsaoko exhibited moderate anti-bacterial activity. The $S$. 

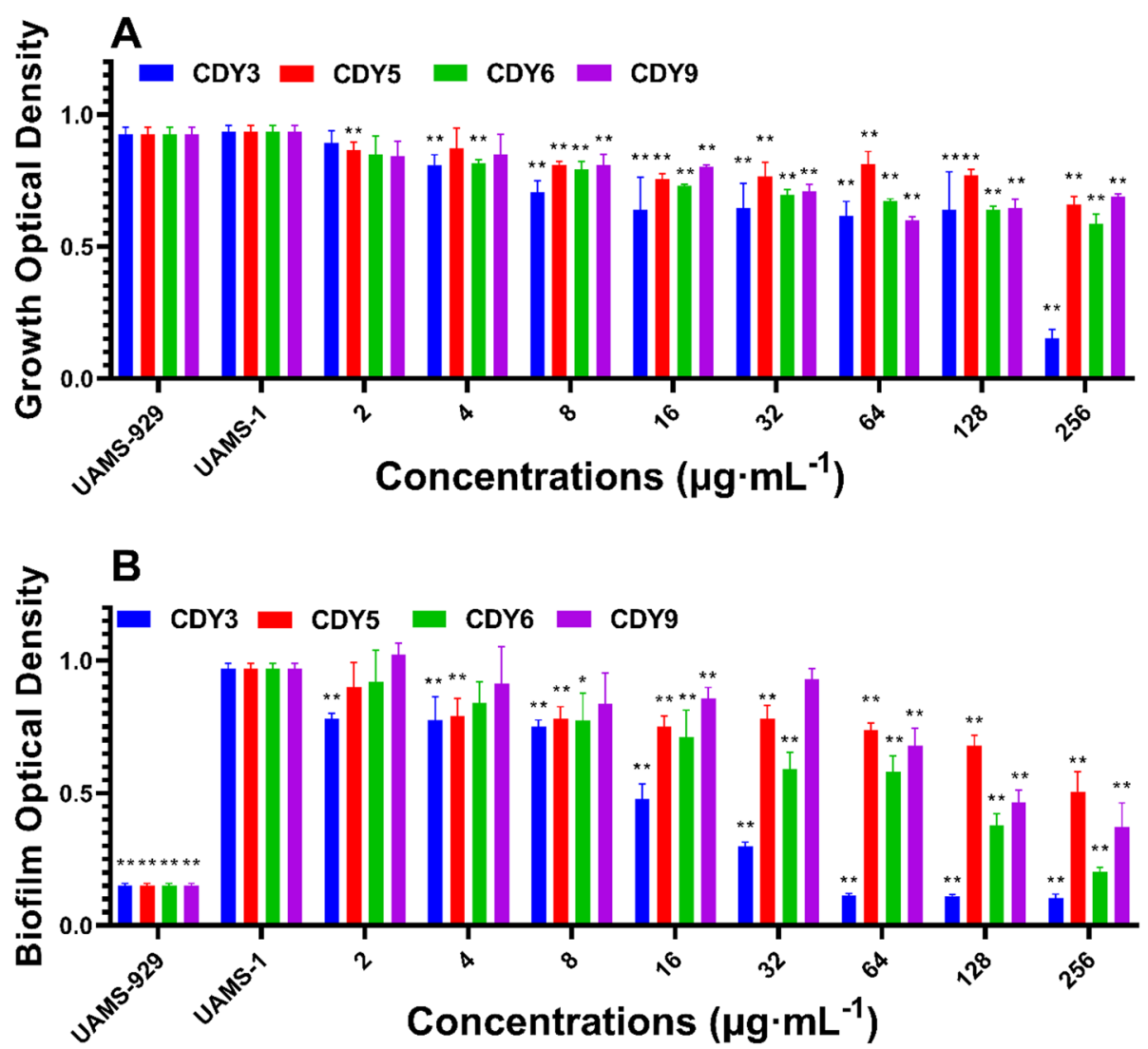

Fig. 4 Inhibition of S. aureus biofilm formation by extracts. Growth and biofilm inhibition of CDY3, 5, 6, and 9 against UAMS-1. The OD $595 \mathrm{~nm}$ is plotted along with OD $600 \mathrm{~nm}$, measured by transfer of the well supernatants to a new 96 -well plate.* $p<0.05$ or ** $p<0.01$ vs. UAMS-1

officinalis ethanol extract had better anti-bacterial activity than the aqueous extract [26] and was effective against both $A$. baumannii and $S$. aureus, whereas the aqueous extract was only active against $A$. baumannii. In previous studies, the $S$. officinalis extract exhibited weak antibacterial activity, and the polyphenolic ingredients possessed antibacterial activity with an MIC were from 0.78 to $25 \mathrm{mg} / \mathrm{mL}$ when tested against different pathogens, including Gram-negative bacteria (Escherichia coli and Salmonella typhimurium) and Grampositive bacteria (Staphylococcus aureus, Listeria monocytogenes and Bacillus subtilis) [27]. The A. tsaoko ethanol extract exhibited anti-bacterial activity against $A$. baumannii and $P$. aeruginosa, whereas the aqueous extract did not. Most previous studies have examined the antibacterial activity of the extract or volatile oil of $A$. tsaoko, and although some results implied that they had antibacterial effects, this may be due to the larger concentrations used in these studies [28,29]. S. officinalis is a TCM, which be used to treat hemorrhoids, wounds, and ulcers in Eastern Asian countries [30]. Previous research involving extraction and pharmacological studies of this herb have been carried out to assess its anti-viral, anti-inflammation, anti-bacterial, anti-tumor, and immunomodulation properties [31-33]. A. tsaoko is widely used in TCM to treat stomach disorders, malaria, throat infections, diarrhea, dyspepsia, nausea, and abdominal pain, and some researchers have reported it to have broad anti-bacterial, anti-tumor, and antiinflammatory activity [34-36]. In this study, we have made the first evaluation the activity of these extracts on multidrug-resistant bacteria, and shown that they had limited growth inhibition activity. Some previous studies support our conclusion by showing that most of these extracts only have antibacterial activity when used at $\mathrm{mg}$ level concentrations.

Because these extracts exhibited limited anti-bacterial activity, this raises the question of why A. tsaoko, S. officinalis, T. chebula, and S.miltiorrhiza are still used in TCM to treat infectious diseases [37-39]. Recent studies have shown that information exchange occurs between bacteria. Many bacteria can synthesize and release a signaling molecule called autoinducer (AI), the extracellular concentration of which increases as bacterial density reaches a critical concentration. AI can active the expression of related genes and regulate the biological behavior of bacteria, including the production of toxins, biofilms, antibiotics, spores, and fluorescence to adapt to 


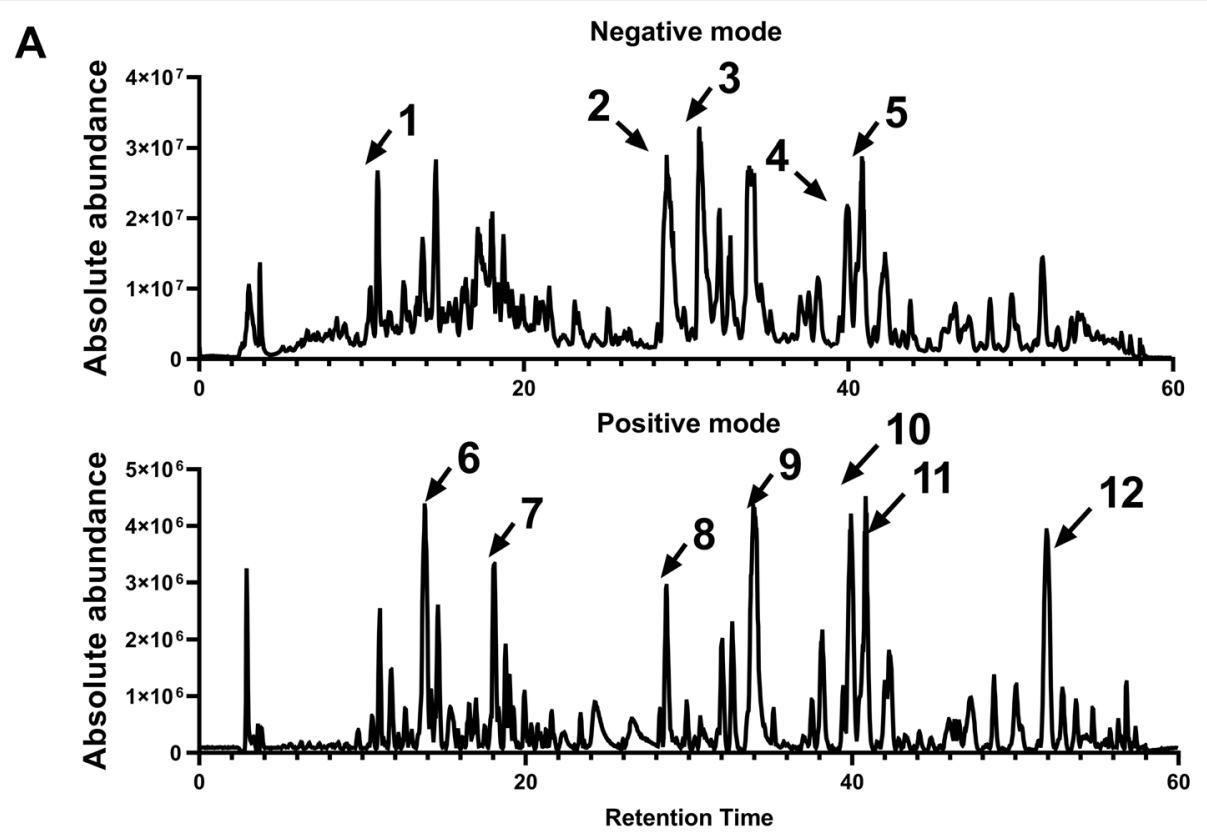

B

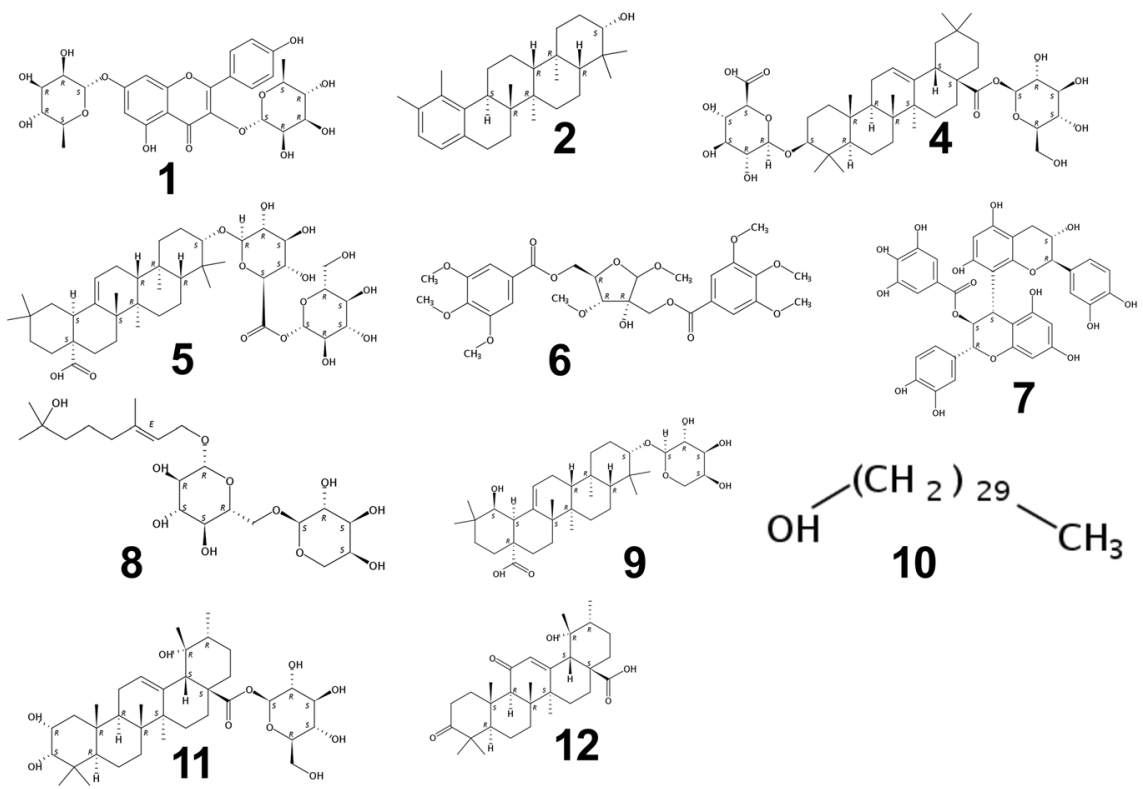

Fig. 5 Chemical characterization of active components of CDY3

changes in the environment. This phenomenon is called quorum sensing [40]. Since this induction phenomenon occurs only after the bacterial density reaches a certain threshold, some people also call this phenomenon cell density dependent control of gene expression [41]. Quorum sensing is closely related to the infectious capacity and pathogenicity of bacteria, and so quorum sensing inhibitors have attracted increasing attention from drug researchers [41]. Research on quorum-sensing inhibitors is considered to be a powerful direction for the study of new antibacterial drugs [42]. We therefore evaluated the quorum quenching activity of the nine extracts on Agr1-4 reporter strains. Most extracts exhibited dose related quorum quenching activity on at least one Agr strain. The S. officinalis ethanol extract, the A. tsaoko organic and aqueous extracts, and the S.miltiorrhiza ethanol extract all exhibited quorum quenching activity without significantly inhibiting bacterial growth. A recent study evaluated the anti-QS activity of the A. tsaoko extract using Chromobacterium violaceum a biosensor 
strain. They showed that it exhibited anti-QS activity in a dose-dependent manner at a concentration range of $0.5-4 \mathrm{mg} / \mathrm{mL}$ [28]. Our study is the first one to use agr reporter strains to evaluate the quorum quenching activity of these extracts.

Quorum sensing were used by bacteria to coordinate certain behaviors, including biofilm formation, virulence, and resistance to antibiotics, depending on their local population density [43, 44]. The extracts with quorum quenching activity (CDY3, 5, 6 and 8) were further evaluated for their ability to inhibit toxin production and biofilm formation. The ethanol extract of S. officinalis, the aqueous extract of $A$. tsaoko, and the ethanol extract of $S$. miltiorrhiza all inhibited $\delta$ toxin production in both $S$. aureus strains NRS 249 and AH1263 without affecting bacterial growth. All four extracts with quorum quenching activity also inhibited the biofilm formation in UAMS-1, with the ethanol extract of $S$. officinalis and the aqueous extract of $A$. tsaoko exhibiting better inhibition activity. The anti-quorum sensing and anti-biofilm activities of A.tsaoko on food borne pathogens have been reported [28]. The ethanol extract of S. officinalis has been shown to inhibit the biofilm formation of MRSA [45]. Some of the polyphenolic compounds in S. officinalis have strong anti-bacterial activity [46]. Some polyphenolic compounds were found in our results and play an important role in inhibiting quorum sensing.

\section{Conclusion}

In conclusion, our study has shown that the ethanol extract of $S$. officinalis has considerable anti-infection capacity against five bacterial strains, and $S$. aureus in particular. It can inhibit bacterial toxin production and biofilm formation at low concentrations and does not promote bacterial proliferation, but can kill bacteria when used at high concentrations. The polyphenolic compounds were highly associated with its antibacterial and quorum quenching activities.. However, the underlying mechanisms still need to be better elucidated in further studies. This is the first comprehensive study examining the anti-virulence activities of the S. officinalis extract via its quorum quenching mechanism, and our results show that it has potential as a novel, natural, anti-infection medicine.

\section{Supplementary information}

The online version contains supplementary material available at https://doi. org/10.1186/s12906-020-03114-z.

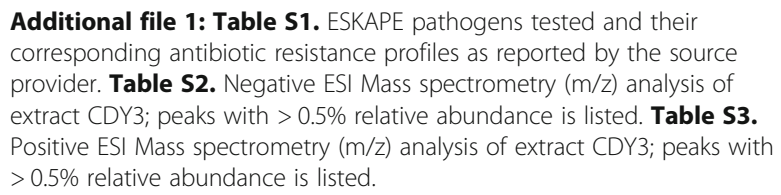

\section{Abbreviations}

WHO: World Health Organization; MRSA: Methicillin-resistant Staphylococcus aureus; agr: Accessory gene regulator; HPLC: High Performance Liquid Chromatography

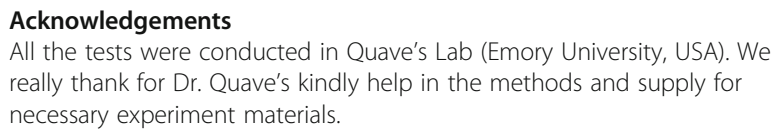

\section{Authors' contributions}

ZP, NL and HT; Methodology, FS and MT; Project administration, MQ and MG; Resources, Writing - original draft, HT; Writing - review \& editing, ZP and $\mathrm{HT}$; All authors have read and agreed to the published version of the manuscript.

\section{Funding}

This work was supported by the National Natural Science Foundation of China (No. 31970137), the Benefit People Project of Science and Technology of Chengdu Science and Technology Bureau (No.2016-HM01-00362-SF), the Scientific Research Fund of Chengdu Medical College (No. CYZ18-18) and the Development and Regeneration Key Laboratory of Sichuan Province, Chengdu Medical College (No.SYS19-08).

\section{Availability of data and materials}

The data used to support the findings of this study are available from the corresponding author upon request.

Ethics approval and consent to participate

Not applicable.

\section{Consent for publication}

Not applicable.

\section{Competing interests}

None of the authors has any conflict of interests regarding this work.

\section{Author details}

${ }^{1}$ School of Laboratory Medicine, Chengdu Medical College, Chengdu, Sichuan, People's Republic of China. 'Laboratory of Veterinary Drug Residue Prevention and Control Technology of Animal-derived Food, Chengdu Medical College, Chengdu, Sichuan, People's Republic of China. ${ }^{3}$ School of Clinical Medical Sciences, Chengdu Medical College, Chengdu, Sichuan, People's Republic of China.

Received: 9 May 2020 Accepted: 9 October 2020

Published online: 19 October 2020

\section{References}

1. Spellberg B, Bartlett JG, Gilbert DN. The future of antibiotics and resistance. N Engl J Med. 2013;368(4):299-302.

2. Frieri M, Kumar K, Boutin A. Antibiotic resistance. J Infect Public Health. 2017;10(4):369-78.

3. Banin E, Hughes D, Kuipers OP. Bacterial pathogens, antibiotics and antibiotic resistance. FEMS Microbiol Rev. 2017;41(3):450-2.

4. Tacconelli E, Carrara E, Savoldi A, Harbarth S, Mendelson M, Monnet DL, Pulcini C, Kahlmeter G, Kluytmans J, Carmeli Y. Discovery, research, and development of new antibiotics: the WHO priority list of antibiotic-resistant bacteria and tuberculosis. Lancet Infect Dis. 2018;18(3):318-27.

5. Fernandes $P$, Martens E. Antibiotics in late clinical development. Biochem Pharmacol. 2017;133:152-63.

6. Z-r L, Zhong Q. Super bacteria and their treatment. World Clin Drugs. 2010;11.

7. Liu X, Steele JC, Meng X-Z. Usage, residue, and human health risk of antibiotics in Chinese aquaculture: a review. Environ Pollut. 2017;223:161-9.

8. Kallen AJ, Mu Y, Bulens S, Reingold A, Petit S, Gershman K, Ray SM, Harrison LH, Lynfield R, Dumyati G. Health care-associated invasive MRSA infections, 2005-2008. JAMA. 2010;304(6):641-7.

9. Nordmann P, Dortet L, Poirel L. Carbapenem resistance in Enterobacteriaceae: here is the storm! Trends Mol Med. 2012;18(5):263-72. 
10. Muhs A, Lyles JT, Parlet CP, Nelson K, Kavanaugh JS, Horswill AR, Quave CL Virulence inhibitors from Brazilian peppertree block quorum sensing and abate dermonecrosis in skin infection models. Sci Rep. 2017;7:42275.

11. Wong R, Hägg U, Samaranayake L, Yuen M, Seneviratne C, Kao R. Antimicrobial activity of Chinese medicine herbs against common bacteria in oral biofilm. A pilot study. Int J Oral Maxillofac Surg. 2010;39(6):599-605.

12. Wang J, Cui M, Jiao H, Tong Y, Xu J, Zhao Y, Han M, Liu J. Content analysis of systematic reviews on the effectiveness of traditional Chinese medicine. J Tradit Chin Med. 2013;33(2):156-63.

13. Chen KC, Sun MF, Yang SC, Chang SS, Chen HY, Tsai FJ, Chen CYC. Investigation into potent inflammation inhibitors from traditional Chinese medicine. Chem Biol Drug Des. 2011;78(4):679-88.

14. Ma H-D, Deng Y-R, Tian Z, Lian Z-X. Traditional Chinese medicine and immune regulation. Clin Rev Allergy Immunol. 2013;44(3):229-41.

15. Lau D, Plotkin BJ. Antimicrobial and biofilm effects of herbs used in traditional Chinese medicine. Nat Prod Commun. 2013;8(11):1617-20.

16. Khan MF, Tang H, Lyles JT, Pineau R, Quave CL. Antibacterial properties of medicinal plants from Pakistan against multidrug-resistant ESKAPE pathogens. Front Pharmacol. 2018;9:815.

17. Schultz F, Anywar G, Tang H, Chassagne F, Lyles JT, Garbe LA, Quave CL. Targeting ESKAPE pathogens with anti-infective medicinal plants from the greater Mpigi region in Uganda. Sci Rep. 2020;10(1):11935.

18. Quave CL, Horswill AR. Identification of Staphylococcal Quorum Sensing Inhibitors by Quantification of õ-Hemolysin with High Performance Liquid Chromatography. Methods Mol Biol. 2018;1673:363-70.

19. Quave $C L$, Horswill AR: Identification of staphylococcal quorum sensing inhibitors by quantification of ö-hemolysin with high performance liquid chromatography. In: Quorum Sensing edn: Springer; 2018: 363-370.

20. Quave CL, Estévez-Carmona M, Compadre CM, Hobby G, Hendrickson H, Beenken KE, Smeltzer MS. Ellagic acid derivatives from Rubus ulmifolius inhibit Staphylococcus aureus biofilm formation and improve response to antibiotics. PLoS One. 2012;7(1). https://doi.org/10.1371/journal.pone.0028737.

21. Beenken KE, Blevins JS, Smeltzer MS. Mutation of sarA in Staphylococcus aureus limits biofilm formation. Infect Immun. 2003;71(7):4206-11.

22. Quave CL, Lyles JT, Kavanaugh JS, Nelson K, Parlet CP, Crosby HA, Heilmann KP, Horswill AR. Castanea sativa (European chestnut) leaf extracts rich in Ursene and Oleanene derivatives block Staphylococcus aureus virulence and pathogenesis without detectable resistance. PLoS One. 2015;10(8): e0136486.

23. Robinson DA, Monk AB, Cooper JE, Feil EJ, Enright MC. Evolutionary genetics of the accessory gene regulator (agr) locus in Staphylococcus aureus. J Bacteriol. 2005;187(24):8312-21.

24. Park J, Jagasia R, Kaufmann GF, Mathison JC, Ruiz DI, Moss JA, Meijler MM, Ulevitch RJ, Janda KD. Infection control by antibody disruption of bacterial quorum sensing signaling. Chem Biol. 2007;14(10):1119-27.

25. Y-y X, X-y H, Xie J, Y-n C, Wang L. Analysis and experience of clinical pharmacists participating in anti-infection consultation in obstetrics department. China Pharm. 2013;24(6):570-72.

26. Gawron-Gzella A, Witkowska-Banaszczak E, Bylka W, Dudek-Makuch M, Odwrot A, Skrodzka N. Chemical composition, antioxidant and antimicrobial activities of Sanquisorba officinalis L Extracts. Pharm Chem J. 2016;50(4):244-9.

27. Zhu H-I, Chen G, Chen S-N, Wang Q-R, Wan L, Jian S-P. Characterization of polyphenolic constituents from Sanguisorba officinalis $L$. and its antibacterial activity. Eur Food Res Technol. 2019;245(7):1487-98.

28. Rahman MRT, Lou Z, Yu F, Wang P, Wang H. Anti-quorum sensing and antibiofilm activity of Amomum tsaoko (Amommum tsao-ko Crevost et Lemarie) on foodborne pathogens. Saudi J Biol Sci. 2017;24(2):324-30.

29. Guo N, Zang Y-P, Cui Q, Gai Q-Y, Jiao J, Wang W, Zu Y-G, Fu Y-J. The preservative potential of Amomum tsaoko essential oil against E. coil, its antibacterial property and mode of action. Food Control. 2017;75:236-45.

30. de Oliveira JR, Vilela P, Almeida RBA, de Oliveira FE, Carvalho CAT, Camargo SEA, Jorge AOC, de Oliveira LD. Antimicrobial activity of noncytotoxic concentrations of Salvia officinalis extract against bacterial and fungal species from the oral cavity. Gen Dent. 2019;67(1):22-6.

31. Su XD, Guo RH, Yang SY, Kim YH, Kim YR. Anti-bacterial effects of components from Sanguisorba officinalis $L$. on Vibrio vulnificus and their soluble epoxide hydrolase inhibitory activity. Nat Prod Res. 2019;33(23): 3445-9.

32. Cai Z, Li W, Wang H, Yan W, Zhou Y, Wang G, Cui J, Wang F. Anti-tumor and immunomodulating activities of a polysaccharide from the root of Sanguisorba officinalis L. Int J Biol Macromol. 2012;51(4):484-8.
33. Kim TG, Kang SY, Jung KK, Kang JH, Lee E, Han HM, Kim SH. Antiviral activities of extracts isolated from Terminalis chebula Retz., Sanguisorba officinalis L., Rubus coreanus Miq. And Rheum palmatum L. against hepatitis B virus. Phytother Res. 2001;15(8):718-20.

34. Lim T. Amomum tsao-ko. In: Edible Medicinal And Non-Medicinal Plants: Springer; 2013. p. 813-7.

35. Yang Y, Yan RW, Cai XQ, Zheng ZL, Zou GL. Chemical composition and antimicrobial activity of the essential oil of Amomum tsao-ko. J Sci Food Agric. 2008;88(12):2111-6.

36. Li B, Choi H-J, Lee D-S, Oh H, Kim Y-C, Moon J-Y, Park W-H, Park S-D, Kim JE. Amomum tsao-ko suppresses lipopolysaccharide-induced inflammatory responses in RAW264. 7 macrophages via Nrf2-dependent heme oxygenase-1 expression. Am J Chin Med. 2014;42(05):1229-44.

37. Shu-de D. Research Progress of Amomum tsao-ko in China. J Anhui Agric Sci. 2009;28.

38. Zuo G, Wang G, Xu G, Yu W, Peng H, Kuang W. Screen of anti-MRSA activity from 30 Chinese herbage medicine extracts. Chin J Mod Appl Pharm. 2006: 23(4):293-5.

39. Zhong X, Shi Y, Chen J, Xu J, Wang L, Beier RC, Hou X, Liu F. Polyphenol extracts from Punica granatum and Terminalia chebula are antiinflammatory and increase the survival rate of chickens challenged with Escherichia coli. Biol Pharm Bull. 2014;37(10):1575-82.

40. Vattem D, Mihalik K, Crixell S, McLean R. Dietary phytochemicals as quorum sensing inhibitors. Fitoterapia. 2007:78(4):302-10.

41. Suga $\mathrm{H}$, Smith KM. Molecular mechanisms of bacterial quorum sensing as a new drug target. Curr Opin Chem Biol. 2003;7(5):586-91.

42. Raffa RB, lannuzzo JR, Levine DR, Saeid KK, Schwartz RC, Sucic NT, Terleckyj $\mathrm{OD}$, Young JM. Bacterial communication ("quorum sensing") via ligands and receptors: a novel pharmacologic target for the design of antibiotic drugs. J Pharmacol Exp Ther. 2005;312(2):417-23.

43. Bassler BL, Ng W-L, Perez L, Cong J, Semmelhack MF. Broad spectrum proquorum-sensing molecules as inhibitors of virulence in vibrios. In: Google Patents; 2017.

44. Kalia VC, Patel SK, Kang YC, Lee J-K. Quorum sensing inhibitors as antipathogens: biotechnological applications. Biotechnol Adv. 2019;37(1):68-90.

45. Chen X, Shang F, Meng Y, Li L, Cui Y, Zhang M, Qi K, Xue T. Ethanol extract of Sanguisorba officinalis $L$. inhibits biofilm formation of methicillin-resistant Staphylococcus aureus in an Ica-dependent manner. J Dairy Sci. 2015;98(12): 8486-91.

46. Pinho E, Ferreira ICFR, Barros L, Carvalho AM, Soares G, Henriques M. Antibacterial potential of northeastern Portugal wild plant extracts and respective phenolic compounds. Biomed Res Int. 2014;2014:814590.

\section{Publisher's Note}

Springer Nature remains neutral with regard to jurisdictional claims in published maps and institutional affiliations.

\section{Ready to submit your research? Choose BMC and benefit from:}

- fast, convenient online submission

- thorough peer review by experienced researchers in your field

- rapid publication on acceptance

- support for research data, including large and complex data types

- gold Open Access which fosters wider collaboration and increased citations

- maximum visibility for your research: over $100 \mathrm{M}$ website views per year

At $\mathrm{BMC}$, research is always in progress.

Learn more biomedcentral.com/submission 